Otentik's: Jurnal Hukum Kenotariatan (Vol 2, No. 1, Januari 2020)

p-ISSN 2655-5131 e-ISSN 2685-3612

\title{
PERLINDUNGAN HUKUM TERHADAP NOTARIS PENGGANTI DALAM PROSES PENYIDIKAN TERKAIT PEMANGGILAN NOTARIS PENGGANTI
}

\author{
NAZILI ABDUL AZIS \\ naziliabdulazis1994@gmail.com
}

\begin{abstract}
Abstrak
Dalam perkembangan zaman, tindak pidana dilakukan semakin kompleks, melintasi batas-batas yurisdiksi dan menggunakan modus yang semakin variatif dengan memanfaatkan Notaris sebagai Lembaga yang mempunyai rahasia jabatan, baik yang dilakukan oleh Notaris yang bersangkutan maupun dilakukan oleh klien Notaris. Penyebab tindak pidana lainnya dapat ditimbulkan secara langsung akibat kelalaian Notaris, namun juga bisa timbul secara tidak langsung dalam hal dilakukan oleh orang lain (klien). Sehingga Penyidik, Penuntut Umum atau Hakim sebagai Penegak Hukum membutuhkan keterangan Notaris untuk memperkuat alat bukti berupa Akta Otentik yang dibuat oleh Notaris bersangkutan. Penegak Hukum dalam melakukan pengambilan Minuta Akta dan/atau Notaris Pengganti wajib untuk mendapatkan persetujuan dari Majelis Kehormatan Notaris sesuai dengan ketentuan Pasal 66 Ayat (1) UUJN dan Pasal 20 Permenkumham MKN. Namun dalam ketentuan Pasal 66 Ayat (1) UUJN dan Pasal 20 Permenkumham MKN belum mengatur ketentuan mengenai pengambilan Minuta Akta dan pemanggilan Notaris terhadap Notaris Pengganti yang berakibat terjadi perbedaan penerapan ketentuan Pasal 66 Ayat (1) UUJN dan Pasal 20 Permenkumham MKN yang peneliti dapatkan pada Majelis Kehormatan Notaris Wilayah Provinsi DKI Jakarta dan Majelis Kehormatan Notaris Wilayah Provinsi Banten. Dalam penelitian ini Metode Penelitian yang digunakan adalah Metodologi Penelitian Hukum Normatif (Normative Legal Research Method) yang disebut juga dengan penelitian kepustakaan atau studi dokumen, disebabkan penelitian ini lebih banyak dilakukan terhadap data yang bersifat sekunder yang ada diperpustakaan. Sehubungan dengan perlindungan hukum terhadap Notaris Pengganti yang "belum" diuraikan dalam ketentuan Pasal 66 Ayat (1) UUJN dan Pasal 20 Permenkumham MKN, dengan harapan agar terjadi penyeragaman dalam menerapkan ketentuan Pasal Pasal 66 Ayat (1) UUJN dan Pasal 20 Permenkumham MKN.
\end{abstract}

Kata Kunci: Majelis Kehormatan Notaris, Pemanggilan Notaris, Notaris Pengganti

\begin{abstract}
Throughout the time, the complexity of criminal act has exceed beyond the limitations of jurisdiction and it uses more variation of approaches in taking advantages of Notary Public - as an institution which possesses confidential information concerning position involves the Notary Public or their clients. Not only derived from the negligence of the Notary Public itself, but the crime might be resulted from the indirect impact from the action of their client. Even an inquirer, public prosecutor, or judges as the law enforcers need the testimony from the notary public to strengthen the evidence which incorporates authentic deed made by the concerned Notary Public. Law enforcers in recording the minutes of the deed and/or the Substitute Notary Public is obligated to obtain agreement from the Notary Honorary Assembly pursuant to the Art. 66(1) of
\end{abstract}


Otentik's: Jurnal Hukum Kenotariatan (Vol 2, No. 1, Januari 2020)

p-ISSN 2655-5131 e-ISSN 2685-3612

UUJN and Art. 20 Minister of Law and Human Rights Regulation concerning MKN has not regulated concerning the requirement of collection of the minute of the deed and to summon the notary public towards a notary which causes contradictions in the implementation of Art. 66(1) UUJN and Art. 20 of the Minister regulation a quo that the researcher has found on the Notary Honorary Assembly in the DKI Jakarta and Banten. Thus, the research will involve normative legal research method, which also referred as library research or document research because the data only involves secondary data obtained from library documents. Subsequently, this thesis would address the legal protection over the Temporary Notary which is not regulated under the Act and Minister Regulation a quo with hope there will be a uniformity over the implementation of the Act and Minister Regulation a quo.

Keyword: Honorary Assembly of Notary Public, The Summoning of Notary Public, Substitute Notary.

\section{PENDAHULUAN}

Negara Republik Indonesia sebagai negara hukum berdasarkan Pancasila dan Undang-Undang Dasar Negara Republik Indonesia Tahun 1945 (yang selanjutnya disingkat "UUDNRI Tahun 1945") menjamin kepastian, ketertiban, dan perlindungan hukum bagi setiap warga negara. Untuk menjamin kepastian, ketertiban dan perlindungan hukum dibutuhkan alat bukti tertulis yang bersifat Otentik mengenai perbuatan, perjanjian, penetapan dan peristiwa hukum yang dibuat dihadapan atau oleh pejabat yang berwenang ${ }^{1}$. Pejabat yang berwenang sebagaimana dimaksud salah satunya adalah Notaris.

Notaris adalah pejabat umum yang mempunyai kewenangan sebagaimana tertuang dalam ketentuan Pasal 15 ayat (1) Undang-Undang Republik Indonesia Nomor 30 Tahun 2004 Undang-Undang Republik Indonesia Nomor 2 Tahun 2014 tentang Perubahan Atas Undang-Undang Republik Indonesia Nomor 30 Tahun 2004 tentang Jabatan Notaris (yang selanjutnya disingkat "UUJN") yaitu membuat Akta Otentik mengenai semua perbuatan, perjanjian dan penetapan yang diharuskan oleh peraturan perundang-undangan dan/atau yang dikehendaki oleh yang berkepentingan untuk dinyatakan dalam Akta Otentik, menjamin kepastian tanggal pembuatan Akta,menyimpan Akta, memberikan grosse, salinan dan kutipan Akta, semuanya itu sepanjang pembuatan Akta itu tidak juga ditugaskan atau dikecualikan kepada pejabat lain atau orang lain yang ditetapkan oleh undang-undang. Berdasarkan ketentuan Pasal 1866 KUH Perdata, Akta Otentik yang dibuat oleh/dihadapan Notaris merupakan alat bukti tulisan atau surat pembuktian yang

\footnotetext{
${ }^{1}$ M. Lutfhfan Hadi Darus, Hukum Notariat dan Tanggungjawab Jabatan Notaris, (Yogyakarta: UII Press, 2017), HIm 1.
} 
Otentik's: Jurnal Hukum Kenotariatan (Vol 2, No. 1, Januari 2020)

p-ISSN 2655-5131 e-ISSN 2685-3612

utama sehingga dokumen ini merupakan alat bukti persidangan yang memiliki kedudukan yang sangat penting ${ }^{2}$.

Ketentuan Pasal 4 ayat (1) dan Pasal 16 ayat (1) huruf f UUJN menguraikan bahwa Notaris adalah pekerjaan terhormat yang dalam menjalankan wewenangnya Notaris telah bersumpah/berjanji untuk menjaga kerahasiaan mengenai Akta yang dibuatnya dan segala keterangan yang diperoleh guna pembuatan Akta, kecuali undang-undang menentukan lain. Ketentuan Pasal 4 ayat (1) dan Pasal 16 ayat (1) huruf f UUJN tersebut merupakan penerapan dari kewajiban ingkar/Verschoningsplicht. Selain dari kewajiban ingkar/Verschoningsplicht, Notaris juga disertai dengan hak ingkar/Verschoningrecht serta kewajiban memberikan keterangan atas akta yang dibuatnya ${ }^{3}$.

Penerapan dari hak ingkar/Verschoningrecht yang melekat pada Notaris dapat kita lihat dalam ketentuan Pasal 1909 angka 3 Kitab Undang-Undang Hukum Perdata/Burgerlijk Wetboek voor Indonesie (yang selanjutnya disingkat "KUH Perdata) yang menguraikan bahwa semua orang yang cakap untuk menjadi saksi, wajib memberikan kesaksian di muka Hakim. Namun dapatlah meminta dibebaskan dari kewajiban memberikan kesaksian terhadap siapa saja karena kedudukannya, pekerjaannya atau jabatannya diwajibkan undang-undang untuk merahasiakan sesuatu, namun hanya mengenai hal-hal yang dipercayakan kepadanya karena kedudukan, pekerjaan dan jabatannya itu.

Selain mempunyai hak dan kewajiban untuk menjaga rahasia dari Akta Otentik yang dibuatnya, Notaris sebagai Warga Negara Indonesia juga mempunyai kewajiban untuk memenuhi panggilan Penyidik dan memberikan keterangan yang sebenarnya untuk membantu Penyidik dalam membuat terang tindak pidana yang terjadi dan guna menemukan tersangkanya sesuai dengan ketentuan Pasal 112 ayat (2) dan Pasal 116 ayat (2) Undang-Undang Nomor 8 Tahun 1981 tentang Hukum Acara Pidana atau dikenal umum sebagai "Kitab Undang-Undang Hukum Acara Pidana" (yang selanjutnya disingkat "KUHAP”).

Ketentuan Pasal 66 ayat (1) UUJN sebagai ketentuan yang memenuhi asas Lex Specialis Derogat Lex Generalis (hukum yang khusus dapat mengesampingkan hukum yang umum) serta asas Lex Posterior Derogat Lex Priori (hukum yang terbaru dapat mengesampingkan hukum yang lama) diundangkan guna menjawab kewajiban

\footnotetext{
2 Paulus J. Soepratignya, Teknik Pembuatan Akta Kontrak, (Yogyakarta: Cahaya Atma Pustaka, 2012), HIm 20.

3 Hukum Online, Miliki Hak Ingkar, Notaris Wajib Rahasiakan Isi Akta, (05 Juli 2012) terdapat disitus https://www.hukumonline.com/berita/baca/lt4ff5751b7abce/miliki-hak-ingkar--notaris-wajib-rahasiakan-isi-akta/, diunduh pada tanggal 18 Januari 2020, pada pukul 10.22 W.I.B.
} 
Otentik's: Jurnal Hukum Kenotariatan (Vol 2, No. 1, Januari 2020)

p-ISSN 2655-5131 e-ISSN 2685-3612

ingkar/Verschoningsplicht, hak ingkar/Verschoningrecht, serta kewajiban memberikan keterangan atas akta yang dibuat Notaris sekaligus, agar kerahasiaan setiap pihak yang terlibat dalam akta dapat tetap terjaga dan proses penyidikan tetap dapat berjalan dengan semestinya.

Ketentuan Pasal 66 ayat (1) UUJN menguraikan bahwa untuk kepentingan peradilan pidana, Penyidik, Penuntut Umum, atau Hakim dalam melakukan pengambilan fotokopi Minuta Akta dan/atau surat-surat yang dilekatkan pada Minuta Akta atau Protokol Notaris dalam penyimpanan Notaris serta memanggil Notaris untuk hadir dalam pemeriksaan yang berkaitan dengan Akta atau Protokol Notaris yang berada dalam penyimpanan Notaris harus dengan persetujuan Majelis Kehormatan Notaris. Persetujuan Majelis Kehormatan Notaris tersebut serta kewajiban Notaris menjaga kerahasiaan mengenai Akta yang dibuatnya dan segala keterangan yang diperoleh guna pembuatan Akta tersebut dapat dikecualikan apabila dalam undang-undang terkait secara jelas menentukan tentang pengambilan fotokopi Minuta Akta dan pemanggilan Notaris, atau sekurang-kurangnya dalam undang-undang menentukan mengenai pengecualian terhadap rahasia jabatan.

Persetujuan pengambilan fotokopi Minuta Akta dan pemanggilan Notaris dalam proses peradilan awalnya merupakan kewenangan dari Majelis Pengawas Daerah sesuai dengan ketentuan Pasal 66 ayat (1) Undang-Undang Republik Indonesia Nomor 30 Tahun 2004 tentang Jabatan Notaris (yang selanjutnya disingkat "PJN"), namun dengan adanya Putusan Mahkamah Konstitusi Republik Indonesia Nomor 49/PUU-X/2012 yang berisi bahwa frasa "dengan persetujuan Majelis Pengawas Daerah" bertentangan dengan ketentuan Pasal 27 ayat (1) dan Pasal 28D ayat (1) UUDNRI Tahun 1945 dan tidak mempunyai kekuatan hukum mengikat, maka diaturlah ketentuan mengenai kewenagan Majelis Kehormatan Notaris sebagai pengganti kewenangan dari Majelis Pengawas Daerah dalam ketentuan Pasal 66 ayat (1) UUJN. Majelis Kehormatan Notaris mempunyai nasib yang sama dengan Majelis Pengawas Daerah yaitu diajukan permohonan uji materi oleh pihak yang sama yaitu Kant Kamal dengan diwakili oleh Tomson Situmeang, S.H. selaku Advokat ke Mahkamah Konstitusi Republik Indonesia dengan permohonan bahwa ketentuan Pasal 66 ayat (1) UUJN sama persis dengan ketentuan Pasal 66 ayat (1) PJN sebelumnya yang hanya dilakukan perubahan terhadap "Baju" atau "Organ" yang memberi persetujuan tidak menghilangkan persamaan substansi kedua aturan tersebut, yaitu tentang memberi persetujuan untuk pengambilan fotokopi Minuta Akta dan Pemanggilan Notaris. Ternyata Majelis Kehormatan Notaris mempunyai akhir cerita yang "bahagia" jika dibandingkan dengan Majelis Pengawas 
Otentik's: Jurnal Hukum Kenotariatan (Vol 2, No. 1, Januari 2020)

p-ISSN 2655-5131 e-ISSN 2685-3612

Daerah, dikarenakan dengan Putusan Mahkamah Konstitusi Republik Indonesia Nomor 72/PUU-XII/2014 yang menyatakan bahwa permohonan tidak dapat diterima. Pada saat ini, Notaris mempunyai 2 (dua) Badan Pembinaan dan Pengawasan Terhadap Notaris yaitu Majelis Pengawas Notaris (yang terbagi menjadi Majelis Pengawas Daerah, Majelis Pengawas Wilayah dan Majelis Pengawas Pusat) dengan kewenangan dan kewajiban untuk melaksanakan pembinaan dan pengawasan terhadap Notaris yang diatur dalam ketentuan Pasal 1 angka 2 dan Pasal 3 ayat (1) Peraturan Menteri Hukum dan Hak Asasi Manusai Republik Indonesia Nomor 40 Tahun 2015 tentang Susunan Organisasi, Tata Cara Pengangkatan Anggota, Pemberhentian Anggota dan Tata Kerja Majelis Pengawas (yang selanjutnya disingkat "Permenkumham MPN") serta Majelis Kehormatan Notaris (yang terdiri dari Majelis Kehormatan Pusat dan Majelis Kehormatan Wilayah) yang mempunyai kewenangan untuk melaksanakan pembinaan Notaris dan kewajiban memberikan persetujuan atau penolakan untuk kepentingan penyidikan dan proses peradilan, atas pengambilan fotokopi Minuta Akta dan pemanggilan Notaris untuk hadir dalam pemeriksaan yang berkaitan dengan Akta atau Protokol Notaris yang berada dalam penyimpanan Notaris yang diatur dalam ketentuan Pasal 1 angka 1 dan Pasal 2 ayat (1) Peraturan Menteri Hukum dan Hak Asasi Manusia Republik Indonesia Nomor 7 Tahun 2016 tentang Majelis Kehormatan Notaris (yang selanjutnya disingkat "Permenkumham MKN").

Ketentuan Pasal 66 ayat (1) UUJN hanya mengatur mengenai pengambilan fotokopi Minuta Akta dan pemanggilan Notaris terhadap Notaris yang masih aktif, sedangkan dalam ketentuan Pasal 65 UUJN menyebutkan bahwa: "Notaris, Notaris Pengganti dan Pejabat Sementara Notaris bertanggung jawab atas setiap Akta yang dibuatnya meskipun Protokol Notaris telah diserahkan atau dipindahkan kepada pihak penyimpan Protokol Notaris". Walau tidak tertuang secara eskplisit dalam ketentuan Pasal 65 UUJN, namun dapat disimpulkan bahwa Notaris masih bertanggung jawab terhadap Akta yang dibuatnya meskipun Notaris tersebut cuti atau telah menjadi Werda Notaris. Hemat peneliti, dalam ketentuan Pasal 65 UUJN tersebut menyatakan bahkan pertanggung jawaban Notaris adalah sampai meninggal dunia.

Dalam ketentuan didalam UUJN belum mengatur pertanggungjawaban Notaris secara pidana. Apabila Notaris melakukan tindakan pidana terkait dengan akta yang dibuatnya maka segala tuntutan/gugatan tetap tunduk pada aturan yang ditetapkan dalam Kitab Undang-Undang Hukum Pidana/Wetboek van Strafrecht (yang selanjutnya 
Otentik's: Jurnal Hukum Kenotariatan (Vol 2, No. 1, Januari 2020)

p-ISSN 2655-5131 e-ISSN 2685-3612

disingkat "KUHP") ${ }^{4}$. Maka dalam menafsirkan ketentuan Pasal 65 UUJN dapat kita kaitkan dengan ketentuan Pasal 77 KUHP" yang berbunyi: "Kewenangan menuntut pidana hapus, jika tertuduh meninggal dunia".

Dengan adanya ketentuan Pasal 77 KUHP serta Pasal 65 UUJN yang mengatur mengenai pertanggung jawaban Notaris terhadap Akta yang dibuat adalah sampai meninggal dunia, mengakibatkan selain pengambilan fotokopi Minuta Akta dan pemanggilan Notaris dapat dilakukan terhadap Notaris masih aktif, sedang cuti maupun telah menjadi Werda Notaris, pengambilan fotokopi Minuta Akta dan pemanggilan Notaris dapat dilakukan pula terhadap Notaris Pengganti. Namun dalam ketentuan Pasal 66 ayat (1) UUJN "belum" mengatur mengenai pengambilan fotokopi Minuta Akta dan pemanggilan Notaris terhadap Notaris Pengganti, sehingga atas penerapan pengambilan fotokopi Minuta Akta dan pemanggilan Notaris terhadap Notaris Pengganti terjadi dubius hukum. Dubius hukum mengenai pengambilan fotokopi Minuta Akta dan pemanggilan Notaris terhadap Notaris Pengganti, penulis temukan pada Majelis Kehormatan Notaris Wilayah Provinsi DKI Jakarta dan Majelis Kehoramatan Notaris Wilayah Provinsi Banten. Majelis Kehormatan Notaris Wilayah Provinsi DKI Jakarta merasa bahwa pengambilan fotokopi Minuta Akta dan pemanggilan Notaris terhadap Notaris Pengganti bukan merupakan kewenangan dari Majelis Kehormatan Notaris Wilayah Provinsi DKI Jakarta, sedangkan Majelis Kehormatan Notaris Wilayah Provinsi Banten merasa bahwa pengambilan fotokopi Minuta Akta dan pemanggilan Notaris terhadap Notaris Pengganti merupakan kewenagan dari Majelis Kehormatan Notaris Wilayah Provinsi Banten.

\section{LANDASAN TEORI}

Pendekatan Teori yang digunakan dalam penelitian ini adalah dengan menggunakan Teori Perlindungan Hukum. Teori Perlindungan Hukum menuruf Fitzgerald pada awalnya merupakan teori yang bersumber dari teori hukum alam (Natural Law) ${ }^{5}$. Fitzgerald mengutip istilah Teori Perlindungan Hukum dari Salmond bahwa Teori Perlindungan Hukum bertujuan untuk mengintegrasikan dan mengkoordinasikan berbagai kepentingan dalam masyarakat karena dalam suatu lalu lintas kepentingan, perlindungan terhadap kepentingan tertentu hanya dapat dilakukan dengan cara membatasi berbagai kepentingan di lain pihak. Kepentingan Hukum adalah mengurusi hak dan kepentingan manusia, sehingga hukum mempunyai otoritas tertinggi untuk menentukan kepentingan

${ }^{4}$ Peter Latumeten, Pertanggungjawaban Hukum Profesi Notaris Bersumber dari Undang-Undang Jabatan Notaris dan Hukum Pidana", (Solo: Diskusi Hukum, 2015), HIm 6.

${ }^{5}$ Satjipto Raharjo, IImu Hukum, (Bandung: PT Citra Aditya Bakti, 2000), HIm 53. 
Otentik's: Jurnal Hukum Kenotariatan (Vol 2, No. 1, Januari 2020)

p-ISSN 2655-5131 e-ISSN 2685-3612

manusia yang perlu diatur dan dilindungi. Perlindungan hukum harus melihat tahapan yakni perlindungan hukum lahir dari suatu ketentuan hukum dan segala peraturan yang diberikan oleh masyarakat yang pada dasarnya merupakan kesepakatan masyarakat tersebut untuk mengatur hubungan perilaku antara anggota-anggota masyarakat dan antara perseorangan dengan pemerintah yang dianggap mewakili kepentingan masyarakat ${ }^{6}$.

Perlindungan Hukum adalah memberikan pengayoman terhadap Hak Asasi Manusia (HAM) yang dirugikan orang lain dan perlindungan itu diberikan kepada masyarakat agar dapat menikmati semua hak-hak yang diberikan oleh hukum ${ }^{7}$.

Dalam ketentuan Pasal 66 ayat (1) UUJN memang tidak menguraikan secara eksplisit mengenai Teori Perlindungan Hukum, namun persetujuan Majelis Kehormatan Notaris atas pengambilan fotokopi Minuta Akta dan pemanggilan Notaris oleh Penyidik, Penuntut Umum atau Hakim dalam proses peradilan tidak lain adalah untuk menerapkan Teori Perlindungan Hukum.

Dalam ketentuan Pasal 26 Permenkumham MKN menguraikan bahwa persetujuan Majelis Kehormatan Notaris atas pengambilan fotokopi Minuta Akta dan pemanggilan Notaris oleh Penyidik, Penuntut Umum atau Hakim dalam proses peradilan dapat dilakukan dalam hal:

1) Adanya dugaan tindak pidana yang berkaitan dengan Minuta Akta dan/atau suratsurat yang dilekatkan pada Minuta Akta atau protokol Notaris dalam penyimpanan Notaris;

2) Belum gugur hak menuntut berdasarkan ketentuan tentang daluarsa dalam peraturan perundang-undangan di bidang hukum pidana;

3) Adanya penyangkalan keabsahan tanda tangan dari salah satu pihak atau lebih;

4) Adanya dugaan pengurangan atau penambahan atas Minuta Akta; atau

5) Adanya dugaan Notaris melakukan pemunduran tanggal (antidatum).

Dalam ketentuan Pasal 26 Permenkumham MKN tersebut jelas menguraikan mengenai Teori Perlindungan Hukum yang terbatas pada ketentuan Pasal 16 ayat (1) huruf f UUJN. Sehingga dapat disimpulkan bahwa Teori Perlindungan Hukum hanya dapat diberlakukan kepada Notaris apabila menyangkut pekerjaannya sebagai Notaris yaitu membuat Akta Otentik. Dalam ketentuan Pasal 1 Angka 7 UUJN menguraikan bahwa Akta Otentik terbagi menjadi 2 (dua) yaitu: 
Otentik's: Jurnal Hukum Kenotariatan (Vol 2, No. 1, Januari 2020)

p-ISSN 2655-5131 e-ISSN 2685-3612

1) Akta Partij/Partij Acte (Akta yang dibuat dihadapan [ten overstain] Notaris); dan

2) Akta Relaas/Ambtelijke Acte (Akta yang dibuat oleh [door] Notaris).

Teori Perlindungan Hukum juga dapat diberlakukan kepada Notaris terkait segala keterangan yang diberikan oleh Penghadap/Klien kepada Notaris agar dapat tersusunnya suatu Akta Otentik.

Dalam ketentuan Pasal 66 ayat (1) UUJN tidak menguraikan mengenai persetujuan Majelis Kehormatan Notaris terhadap pengambilan fotokopi Akta PPAT dan Protokol PPAT serta pemanggilan PPAT dalam proses peradilan, sehingga Teori Perlindungan Hukum oleh Majelis Kehormatan Notaris tidak dapat diterapkan terhadap PPAT. Akta PPAT sebagaimana dijelaskan dalam ketentuan Pasal 2 ayat (2) Peraturan Kepala Badan Pertanahan Nasional Republik Indonesia Nomor 1 Tahun 2006 tentang Ketentuan Pelaksanaan Peraturan Pemerintah Republik Indonesia Nomor 37 Tahun 1998 tentang Peraturan Jabatan Pejabat Pembuat Akta Tanah yang terdiri dari:

1) Akta Jual Beli;

2) Akta Tukar Menukar;

3) Akta Hibah;

4) Akta Pemasukan Ke Dalam Perusahaan (Inbreng);

5) Akta Pembagian Hak Bersama;

6) Akta Pemberian Hak Guna Bangunan/Hak Pakai Atas Tanah Hak Milik;

7) Akta Pemberian Hak Tanggungan;

8) Akta Pemberian Kuasa Membebankan Hak Tanggungan.

Akta Pemberian Kuasa Membebankan Hak Tanggungan sebagaimana dimaksud pada poin 8) adalah Akta yang dapat dibuat baik oleh Notaris ataupun PPAT, sehingga tidak semua Akta Pemberian Kuasa Membebankan Hak Tanggungan tersebut tidak dapat diterapkan mengenai Teori Perlindungan Hukum oleh Majelis Kehormatan Notaris. Akta Pemberian Kuasa Membebankan Hak Tanggungan yang dapat diterapkan mengenai Teori Perlindungan Hukum oleh Majelis Kehormatan Notaris adalah Akta Otentik yang dibuat oleh Notaris, sehingga terhadap Notaris yang merangkap sebagai PPAT perlu dipastikan dalam membuat Akta Pemberian Kuasa Membebankan Hak Tanggungan tersebut dibuat dalam kapasitasnya sebagai Notaris atau PPAT.

Persetujuan Majelis Kehormatan Notaris atas pengambilan fotokopi Minuta Akta dan/atau surat-surat yang dilekatkan pada Minuta Akta atau Protokol Notaris dalam penyimpanan Notaris dalam proses peradilan hanya dilakukan terhadap Notaris yang masih aktif yang diatur dalam ketentuan Pasal 66 ayat (1) UUJN. Namun, mengingat 
Otentik's: Jurnal Hukum Kenotariatan (Vol 2, No. 1, Januari 2020)

p-ISSN 2655-5131 e-ISSN 2685-3612

ketentuan Pasal 65 UUJN yang menguraikan bahwa "Notaris, Notaris Pengganti dan Pejabat Sementara Notaris bertanggung jawab atas setiap Akta yang dibuatnya meskipun Protokol Notaris telah diserahkan atau dipindahkan kepada pihak penyimpan Protokol Notaris", maka jika diperlukan Penyidik, Penuntut Umum atau Hakim dapat memanggil Notaris Pengganti atas Akta Otentik yang dibuatnya pada saat masih aktif yang terindikasi tindak pidana pada Protokol Notaris dalam penyimpanan Notaris. Dalam ketentuan Pasal 66 ayat (1) UUJN belum mengatur mengenai persetujuan Majelis Kehormatan Notaris terhadap pemanggilan Notaris Pengganti dalam proses peradilan, Sehingga Peneliti tertarik untuk meneliti "Perlindungan Hukum Terhadap Notaris Pengganti Dalam Proses Penyidikan Kaitannya Dengan Pemanggilan Notaris Pengganti” menggunakan Teori Perlindungan Hukum sebagai teori yang akan digunakan.

\section{METODE PENELITIAN}

Metodologi yang akan digunakan dalam penelitian ini adalah Metodologi Penelitian Hukum Normatif (Normative Legal Research Method) yang disebut juga dengan penelitian kepustakaan atau studi dokumen, disebabkan penelitian ini lebih banyak dilakukan terhadap data yang bersifat sekunder yang ada diperpustakaan ${ }^{8}$.

\section{RUMUSAN MASALAH}

Bertolak dari uraian latar belakang yang telah diuraikan, selanjutnya perumusan masalah dalam penelitian ini diajukan dengan pertanyaan penelitian (research question) sebagai berikut:

1. Bagaimana hukum yang mengatur mengenai perlindungan hukum terhadap Notaris Pengganti dalam proses penyidikan kaitannya dengan pemanggilan Notaris Pengganti?

2. Bagaimana penerapan perlindungan hukum terhadap Notaris Pengganti dalam proses penyidikan kaitannya dengan pemanggilan Notaris Pengganti pada Majelis Kehormatan Notaris Wilayah Provinsi DKI Jakarta dan Majelis Kehormatan Notaris Wilayah Provinsi Banten?

\section{HASIL PENELITIAN}

Notaris adalah pejabat umum yang mempunyai kewenangan sebagaimana tertuang dalam ketentuan Pasal 15 ayat (1) UUJN yaitu membuat Akta Otentik mengenai semua

8 Tim Penyusun, Pedoman Penulisan Usulan Penelitian \& Tesis Tahun Akademik 2018/2019, (Jakarta: Program Studi Kenotariatan Program Magister Universitas Pancasila, 2018/2019), HIm 32. 
Otentik's: Jurnal Hukum Kenotariatan (Vol 2, No. 1, Januari 2020)

p-ISSN 2655-5131 e-ISSN 2685-3612

perbuatan, perjanjian dan penetapan yang diharuskan oleh peraturan perundang-undangan dan/atau yang dikehendaki oleh yang berkepentingan untuk dinyatakan dalam Akta Otentik, menjamin kepastian tanggal pembuatan Akta, menyimpan Akta, memberikan grosse, salinan dan kutipan Akta, semuanya itu sepanjang pembuatan Akta itu tidak juga ditugaskan atau dikecualikan kepada pejabat lain atau orang lain yang ditetapkan oleh undang-undang.

Ketentuan Pasal 4 ayat (1) dan Pasal 16 ayat (1) huruf f UUJN menguraikan bahwa Notaris adalah pekerjaan terhormat yang dalam menjalankan wewenangnya Notaris telah bersumpah/berjanji untuk menjaga kerahasiaan mengenai Akta yang dibuatnya dan segala keterangan yang diperoleh guna pembuatan Akta, kecuali undang-undang menentukan lain. Dalam Penjelasan Pasal 4 ayat (1) dan Pasal 16 ayat (1) huruf f UUJN menguraikan bahwa "kewajiban" untuk merahasiakan segala sesuatu yang berhubungan dengan Akta dan surat-surat lainnya adalah untuk melindungi kepentingan semua pihak yang terkait dengan Akta tersebut. "Kewajiban" tersebut diatas merupakan implikasi dari peraturan perundang-undangan diantaranya adalah:

Pasal 322 ayat (1) KUHP yang menguraikan bahwa:

"Barang siapa dengan sengaja membuka rahasia yang wajib disimpannya karena jabatan atau pencariannya, baik yang sekarang maupun yang dahulu, diancam dengan penjara pidana paling lama 9 (sembilan) bulan atau pidana denda paling banyak Rp. 9000,(sembilan ribu rupiah)";

Kewajiban untuk merahasiakan segala sesuatu yang berhubungan dengan jabatan tersebut diatas dikenal umum sebagai kewajiban ingkar/Verschoningsplicht. Menurut Soerjono Soekanto kewajiban ingkar dalam hukum dapat diartikan bahwa kewajiban merupakan role atau peranan imperatif karena tidak boleh dilaksanakan ${ }^{9}$.

Istilah Kewajiban Ingkar digunakan dikarenakan suatu jabatan "wajib" untuk merahasiakan segala sesuatu yang berhubungan dengan jabatan tersebut, jika suatu jabatan tidak menjalankan justru akan mendapatkan konsekuensi baik berupa pemberian sanksi, ganti rugi, denda bahkan pidana.

Dalam ketentuan Pasal 16 ayat (11) UUJN, jika Notaris melanggar kewajiban menjalankan jabatan yang salah satunya adalah kewajiban ingkar, maka Notaris dapat dikenai sanksi berupa:

a. Peringatan tertulis;

b. Pemberhentian sementara;

${ }^{9}$ Soerjono Soekanto, Sendi-Sendi Hukum dan Tata Hukum, (Bandung: Citra Aditya Bakti, 1989), HIm 17. 
Otentik's: Jurnal Hukum Kenotariatan (Vol 2, No. 1, Januari 2020)

p-ISSN 2655-5131 e-ISSN 2685-3612

c. Pemberhentian dengan hormat; atau

d. Pemberhentian dengan tidak hormat.

Selain Kewajiban Ingkar/Verschoningsplicht, Notaris sebagai pekerjaan terhormat juga mempunyai Hak ingkar/Verschoningrecht. Menurut Soerjono Soekanto hak ingkar dalam hukum dapat diartikan bahwa hak merupakan role atau peranan fakultatif sifatnya karena boleh tidak dilaksanakan ${ }^{10}$. Lebih lanjut, menurut van Bemmalen ada 3 (tiga) dasar untuk dapat menuntut penggunaan hak ingkar, yakni ${ }^{11}$ :

a. Hubungan keluarga yang sangat dekat;

b. Bahaya dikenakan hukuman pidana (gevaar voor strafrechtelijkke veroordeling);

c. Kedudukan, pekerjaan dan rahasia jabatan.

Istilah Hak Ingkar digunakan dikarenakan suatu jabatan memiliki "hak" yang dapat digunakan maupun tidak untuk merahasiakan segala sesuatu yang berhubungan dengan jabatan tersebut. Hak Ingkar tersebut merupakan implikasi dari peraturan perundangundangan diantaranya adalah:

a. Pasal 1909 angka 3 KUH Perdata yang menguraikan bahwa:

"Semua orang yang cakap untuk menjadi saksi, wajib memberikan kesaksian di muka Hakim. Namun dapatlah meminta dibebaskan dari kewajiban memberikan kesaksian yaitu siapa saja karena kedudukannya, pekerjaannya atau jabatannya diwajibkan undang-undang untuk merahasiakan sesuatu, namun hanya mengenai hal-hal yang dipercayakan kepadanya karena kedudukan, pekerjaan dan jabatannya itu";

b. Pasal 89 ayat (1) huruf b Undang-Undang Republik Indonesia Nomor 5 Tahun 1986 sebagaimana diubah dengan Undang-Undang Republik Indonesia Nomor 9 Tahun 2004 sebagaimana diubah lagi dengan Undang-Undang Republik Indonesia Nomor 51 Tahun 2009 tentang Perubahan Kedua Atas Undang-Undang Republik Indonesia Nomor 5 Tahun 1986 tentang Peradilan Tata Usaha Negara yang menguraikan bahwa:

"Orang yang dapat minta pengunduran diri dari kewajiban untuk memberikan kesaksian ialah setiap orang yang karena martabat, pekerjaan atau jabatannya diwajibkan merahasiakan segala sesuatu yang berhubungan dengan martabat, pekerjaan atau jabatannya itu".

\footnotetext{
${ }_{10}^{11} \mathrm{lbid}$.

11 Laurensius Arliman S, Op.Cit., HIm 217.
} 
Otentik's: Jurnal Hukum Kenotariatan (Vol 2, No. 1, Januari 2020)

p-ISSN 2655-5131 e-ISSN 2685-3612

Selain Kewajiban Ingkar/Verschoningsplicht dan Hak Ingkar/Verschoningrecht, sebagai Warga Negara Indonesia Notaris juga mempunyai kewajiban diantaranya adalah:

a. Pasal 112 ayat (2) KUHAP yang menguraikan bahwa:

"Orang yang dipanggil wajib datang kepada Penyidik dan jika ia tidak datang,

Penyidik memanggil sekali lagi, dengan perintah kepada petugas untuk membawanya";

b. Pasal 116 ayat (2) KUHAP yang menguraikan bahwa:

"Saksi diperiksa secara tersendiri, tetapi boleh dipertemukan yang satu dengan yang

lain dan mereka wajib memberikan keterangan yang sebenarnya."

Dalam perkembangan zaman, tindak pidana dilakukan semakin kompleks, melintasi batas-batas yurisdiksi dan menggunakan modus yang semakin variatif dengan memanfaatkan Notaris sebagai Lembaga yang mempunyai rahasia jabatan, baik yang dilakukan oleh Notaris yang bersangkutan maupun dilakukan oleh klien Notaris. Penyebab tindak pidana lainnya dapat ditimbulkan secara langsung akibat kelalaian Notaris, namun juga bisa timbul secara tidak langsung dalam hal dilakukan oleh orang lain (klien) ${ }^{12}$. Adapun tindak pidana yang berkaitan dengan jabatan Notaris yang diatur dalam beberapa pasal KUHP adalah sebagai berikut:

a. Pasal 242 KUHP yang menguraikan bahwa:

(1). Barang siapa dalam keadaan di mana undang-undang menentukan supaya memberi keterangan di atas sumpah atau mengadakan akibat hukum kepada keterangan yang demikian, dengan sengaja memberi keterangan palsu di atas sumpah, baik dengan lisan atau tulisan, secara pribadi maupun oleh kuasanya yang khusus ditunjuk untuk itu, diancam dengan pidana penjara paling lama 7( tujuh) tahun;

(2). Jika keterangan palsu di atas sumpah diberikan dalam perkara pidana dan merugikan terdakwa atau tersangka, yang bersalah diancam dengan pidana penjara paling lama 9 (sembilan) tahun;

b. Pasal 263 KUHP yang menguraikan bahwa:

(1). Barang siapa membuat surat palsu atau memalsukan surat yang dapat menimbulkan sesuatu hak, perikatan atau pembebasan hutang, atau yang diperuntukkan sebagai bukti daripada sesuatu hal dengan maksud untuk memakai atau menyuruh orang lain memakai surat tersebut seolah-olah isinya

12 Sri Utami, "Perlindungan Hukum Terhadap Notaris Dalam Proses Peradilan Pidana Menurut Undang-Undang Nomor 2 Tahun 2014 Tentang Perubahan Atas Undang-Undang Nomor 30 Tahun 2004 Tentang Jabatan Notaris", artikel pada Jurnal Repertorium, ISSN: 2355-2646, Edisi 3 Januari-Juni 2015. 
Otentik's: Jurnal Hukum Kenotariatan (Vol 2, No. 1, Januari 2020)

p-ISSN 2655-5131 e-ISSN 2685-3612

benar dan tidak dipalsu, diancam jika pemakaian tersebut dapat menimbulkan kerugian, karena pemalsuan surat, dengan pidana penjara paling lama 6 (enam) tahun;

(2). Diancam dengan pidana yang sama, barang siapa dengan sengaja memakai surat palsu atau yang dipalsukan seolah-olah sejati, jika pemakaian surat itu dapat menimbulkan kerugian;

c. Pasal 264 KUHP yang menguraikan bahwa:

(1). Pemalsuan surat diancam dengan pidana penjara paling lama 8 (delapan) tahun, jika dilakukan terhadap akta-akta otentik;

(2). Diancam dengan pidana yang sama barang siapa dengan sengaja memakai surat tersebut dalam ayat pertama, yang isinya tidak sejati atau yang dipalsukan seolah-olah benar dan tidak dipalsu, jika pemalsuan surat itu dapat menimbulkan kerugian;

d. Pasal 266 KUHP yang menguraikan bahwa:

(1). Barang siapa menyuruh memasukkan keterangan palsu ke dalam suatu Akta Otentik mengenai sesuatu hal yang kebenarannya harus dinyatakan oleh akta itu, dengan maksud untuk memakai atau menyuruh orang lain memakai akta itu seolah-olah keterangannya sesuai dengan kebenaran, diancam, jika pemakaian itu dapat menimbulkan kerugian, dengan pidana penjara paling lama 7 (tujuh) tahun;

(2). Diancam dengan pidana yang sama barang siapa dengan sengaja memakai surat tersebut dalam ayat pertama, yang isinya tidak sejati atau yang dipalsukan seolah-olah benar dan tidak dipalsu, jika pemalsuan surat itu dapat menimbulkan kerugian;

e. Pasal 322 KUHP yang menguraikan bahwa:

(1). Barang siapa dengan sengaja membuka rahasia yang wajib disimpannya karena jabatan atau pencariannya, baik yang sekarang maupun yang dahulu, diancam dengan pidana penjara paling lama 9 (sembilan) bulan atau pidana denda paling banyak sembilan ribu rupiah;

(2). Jika kejahatan dilakukan terhadap seorang tertentu, maka perbuatan itu hanya dapat dituntut atas pengaduan orang itu;

\section{f. Pasal 372 KUHP}

"Barang siapa dengan sengaja dan melawan hukum memiliki barang sesuatu yang seluruhnya atau sebagian adalah kepunyaan orang lain, tetapi yang ada dalam 
Otentik's: Jurnal Hukum Kenotariatan (Vol 2, No. 1, Januari 2020)

p-ISSN 2655-5131 e-ISSN 2685-3612

kekuasaannya bukan karena kejahatan diancam karena penggelapan, dengan pidana penjara paling lama 4 (empat) tahun atau pidana denda paling banyak sembilan ratus rupiah."

Dengan memperhatikan Kewajiban Ingkar/Verschoningsplicht, Hak Ingkar/Verschoningrecht, kewajiban untuk memenuhi panggilan Penyidik dan menyampaikan keterangan yang sebenarnya serta menindaklanjuti tindak pidana yang berkaitan dengan jabatan Notaris, agar kepentingan semua pihak yang terkait dengan pembuatan suatu Akta Otentik baik yang dibuat oleh maupun dihadapan Notaris tetap terlindungi namun dengan tetap menjunjung kepentingan proses penyidikan agar tetap dapat berjalan dengan semestinya maka Pemerintah memberikan ketentuan pengecualian dalam UUJN yaitu:

a. Pasal 54 UUJN yang menguraikan bahwa:

"Notaris hanya dapat memberikan, memperlihatkan atau memberitahukan isi Akta, Grosse Akta, Salinan Akta atau Kutipan Akta kepada orang yang berkepentingan langsung pada Akta, Ahli Waris atau orang yang memperoleh hak, kecuali ditentukan lain oleh peraturan perundang-undangan";

b. Pasal 66 ayat (1) UUJN yang menguraikan bahwa:

"Untuk kepentingan proses peradilan, Penyidik, Penuntut Umum atau Hakim dengan persetujuan Majelis Kehormatan Notaris berwenang:

a. Mengambil fotokopi Minuta Akta dan/atau surat-surat yang dilekatkan pada Minuta Akta atau Protokol Notaris dalam penyimpanan Notaris; dan

b. Memanggil Notaris untuk hadir dalam pemeriksaan yang berkaitan dengan Akta atau Protokol Notaris yang berada dalam penyimpanan Notaris.

Dalam UUJN hanya mengatur ketentuan mengenai Notaris yang masih aktif membuat Akta, tidak terkecuali dalam ketentuan Pasal 66 ayat (1) UUJN, sehingga kewenangan dari Majelis Kehormatan Notaris pun hanya terbatas pada Notaris yang masih aktif saja. Dengan pengundangan UUJN yang mengatur sebatas terhadap Notaris yang masih aktif membuat akta saja berakibat dalam melaksanakan penetapan Permenkumham MKN sebagai peraturan turunannya pun tidak boleh bertentangan dengan UUJN, tidak terkecuali dalam ketentuan Pasal 20 Permenkumham MKN. Sehingga dalam ketentuan Pasal 20 Permenkumham MKN pun hanya mengatur mengenai Notaris yang masih aktif saja.

Dalam ketentuan Pasal 66 Ayat (1) UUJN dan Pasal 20 Permenkumham MKN selain hanya mengatur mengenai Notaris yang masih aktif juga "belum" mengatur ketentuan 
Otentik's: Jurnal Hukum Kenotariatan (Vol 2, No. 1, Januari 2020)

p-ISSN 2655-5131 e-ISSN 2685-3612

mengenai Notaris Pengganti, baik Notaris Pengganti yang masih menggantikan Notaris maupun Notaris Pengganti yang sudah berakhir masa jabatannya. Padahal dalam ketentuan Pasal 65 UUJN menguraikan bahwa: "Notaris, Notaris Pengganti dan Pejabat Sementara Notaris bertanggung jawab atas setiap Akta yang dibuatnya meskipun Protokol Notaris telah diserahkan atau dipindahkan kepada pihak penyimpan Protokol Notaris".

Sehingga dalam melaksanakan ketentuan Pasal 66 ayat (1) UUJN dan Pasal 20 Permenkumham MKN pada tiap wilayah terjadi perbedaan penerapan ketentuan Pasal 66 ayat (1) UUJN dan Pasal 20 Permenkumham MKN dikarenakan terjadinya dubius hukum. Tidak terkecuali penerapan pengambilan Minuta Akta dan pemanggilan Notaris terhadap Notaris Pengganti oleh Majelis Kehormatan Notaris Wilayah Provinsi DKI Jakarta dan Majelis Kehormatan Notaris Wilayah Provinsi Banten.

Majelis Kehormatan Notaris Wilayah Provinsi DKI Jakarta memandang bahwa kewenangan Majelis Kehormatan Notaris hanya terbatas pada UUJN dan Permenkumham MKN saja, sehingga dalam pengambilan keputusan terhadap permohonan yang masuk ke Majelis Kehormatan Notaris Wilayah Provinsi DKI Jakarta terbagi menjadi 3 (tiga) yaitu permohonan yang disetujui, permohonan yang ditolak dan permohonan yang bukan kewenangan dari Majelis Kehormatan Notaris Wilayah Provinsi DKI Jakarta sebagaimana penulis susun sesuai tabel dibawah ini:

Tabel 1. Surat Permohonan Masuk Per Bulan Januari Sampai Dengan September Tahun 2019 di Majelis Kehormatan Notaris Wilayah Provinsi DKI Jakarta

\begin{tabular}{|c|c|c|c|c|c|c|c|}
\hline BULAN & $\begin{array}{c}\text { JUMLAH } \\
\text { PERMOHONAN } \\
\text { MASUK }\end{array}$ & \multicolumn{3}{c|}{$\begin{array}{c}\text { BUKAN KEWENANGAN MAJELIS KEHORMATAN } \\
\text { NOTARIS WILAYAH PROVINSI DKI JAKARTA }\end{array}$} \\
\cline { 2 - 8 } & $\begin{array}{c}\text { MENOL } \\
\text { AK }\end{array}$ & $\begin{array}{c}\text { MENERI } \\
\text { MA }\end{array}$ & $\begin{array}{c}\text { WERD } \\
\text { A } \\
\text { NOTA } \\
\text { RIS }\end{array}$ & $\begin{array}{c}\text { PPA } \\
\text { T }\end{array}$ & $\begin{array}{c}\text { MENING } \\
\text { GAL } \\
\text { DUNIA }\end{array}$ & $\begin{array}{c}\text { TIDAK } \\
\text { BERKEDUD } \\
\text { UKAN DI } \\
\text { DKI } \\
\text { JAKARTA }\end{array}$ & $\begin{array}{c}\text { NOTARIS } \\
\text { PENGGA } \\
\text { NTI }\end{array}$ \\
\hline Januari & 5 & 6 & 2 & 1 & & & \\
\hline Februari & 13 & 10 & 1 & & & 1 & \\
\hline Maret & 11 & 9 & 1 & & & & \\
\hline April & 12 & 6 & & 2 & & & \\
\hline Mei & 6 & 5 & & & 1 & & \\
\hline Juni & 3 & 6 & & 1 & & & \\
\hline Juli & 8 & 5 & 3 & & 3 & & \\
\hline Agustus & 9 & 2 & 1 & & & 1 & \\
\hline $\begin{array}{c}\text { Septemb } \\
\text { er }\end{array}$ & 7 & 3 & & & & & \\
\hline
\end{tabular}


Otentik's: Jurnal Hukum Kenotariatan (Vol 2, No. 1, Januari 2020)

p-ISSN 2655-5131 e-ISSN 2685-3612

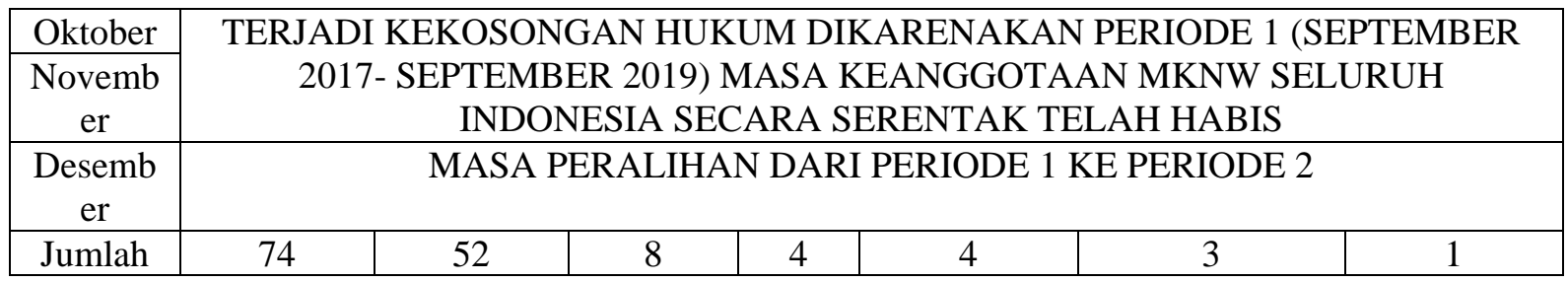

Sumber: Majelis Kehormatan Wilayah Provinsi DKI Jakarta.

Dari data yang didapat peneliti dari Majelis Kehormatan Notaris Wilayah Provinsi DKI Jakarta menguraikan bahwa Majelis Kehormatan Notaris Wilayah Provinsi DKI Jakarta tidak berwenang untuk memberikan persetujuan atas:

a. Werda Notaris;

Dalam surat permohonan yang masuk ke Majelis Kehormatan Notaris Wilayah

Provinsi DKI Jakarta yang bukan kewenangan dari Majelis Kehormatan Notaris

Wilayah Provinsi DKI Jakarta dengan jumlah tertinggi ditahun 2019 yaitu Werda Notaris dengan jumlah 8 (delapan) orang. Majelis Kehormatan Notaris Wilayah Provinsi DKI Jakarta menyatakan tidak berwenang untuk memberikan persetujuan terhadap Werda Notaris dikarenakan UUJN dan Permenkumham MKN hanya mengatur mengenai Notaris yang masih aktif saja. Surat permohonan yang masuk adalah surat permohonan untuk mengambil Minuta Akta yang dibuat saat Notaris masih aktif yang berada dalam penyimpanan Notaris dan/atau memanggil Werda Notaris untuk memberikan keterangan terkait Akta yang dibuatnya semasa aktif. Jika yang diperlukan oleh Penyidik adalah Minuta Akta dalam penyimpanan Notaris, maka Majelis Kehormatan Notaris Wilayah Provinsi DKI Jakarta akan memberikan jawaban berupa memberikan persetujuan atau penolakan terhadap permohonan tersebut. Jika yang diperlukan oleh Penyidik adalah keterangan dari Werda Notaris maka bukan kewenangan dari Majelis Kehormatan Notaris Wilayah Provinsi DKI Jakarta.

Majelis Kehormatan Notaris Wilayah Provinsi DKI Jakarta dalam mengetahui informasi mengenai keaktifan Notaris terkait berkoordinasi dengan Majelis Pengawas Daerah setempat. Jika Notaris tersebut telah pensiun (Werda Notaris), maka Majelis Kehormatan Notaris Wilayah Provinsi DKI Jakarta menyatakan tidak berwenang untuk memberikan persetujuan tanpa perlu diadakan sidang terhadap Notaris terkait.

b. Pejabat Pembuat Akta Tanah (PPAT);

Surat permohonan yang masuk ke Majelis Kehormatan Notaris Wilayah Provinsi DKI Jakarta yang bukan kewenangan dari Majelis Kehormatan Notaris Wilayah Provinsi DKI Jakarta diurutan tertinggi kedua ditahun 2019 yaitu PPAT 4 (empat) orang. Surat Permohonan terhadap pemanggilan PPAT disini adalah Notaris yang merangkap jabatan PPAT atau seseorang yang baru menjabat sebagai PPAT saja yang membuat Akta PPAT yang sebagaimana dijelaskan dalam ketentuan Pasal 2 ayat (2) Peraturan Kepala Badan Pertanahan Nasional Republik Indonesia Nomor 1 Tahun 2006 tentang Ketentuan Pelaksanaan Peraturan Pemerintah Republik Indonesia Nomor 37 Tahun 1998 tentang Peraturan Jabatan Pejabat Pembuat Akta Tanah yang terdiri dari: 
Otentik's: Jurnal Hukum Kenotariatan (Vol 2, No. 1, Januari 2020)

p-ISSN 2655-5131 e-ISSN 2685-3612

1) Akta Jual Beli;

2) Akta Tukar Menukar;

3) Akta Hibah;

4) Akta Pemasukan Ke Dalam Perusahaan (Inbreng);

5) Akta Pembagian Hak Bersama;

6) Akta Pemberian Hak Guna Bangunan/Hak Pakai Atas Tanah Hak Milik;

7) Akta Pemberian Hak Tanggungan;

8) Akta Pemberian Kuasa Membebankan Hak Tanggungan.

Akta Pemberian Kuasa Membebankan Hak Tanggungan sebagaimana dimaksud pada poin 8) adalah Akta yang dapat dibuat baik oleh Notaris ataupun PPAT, sehingga Akta Pemberian Kuasa Membebankan Hak Tanggungan yang dibuat oleh PPAT adalah bukan kewenangan dari Majelis Kehormatan Notaris Wilayah Provinsi DKI Jakarta.

Sehingga dalam permohonan persetujuan terhadap pengambilan Minuta Akta maupun pengambilan PPAT, Majelis Kehormatan Notaris Wilayah Provinsi DKI Jakarta menyatakan tidak berwenang untuk memberikan persetujuan atas hal tersebut.

Dalam hal surat permohonan masuk adalah pengambilan Minuta Akta maupun permohonan pemanggilan PPAT, maka Majelis Kehormatan Wilayah Provinsi DKI Jakarta tetap melakukan pembentukan Majelis Pemeriksa dan melakukan sidang terhadap PPAT tersebut untuk memastikan PPAT tersebut merangkap Notaris atau tidak.

c. Notaris Meninggal Dunia;

Surat permohonan yang masuk ke Majelis Kehormatan Notaris Wilayah Provinsi DKI Jakarta yang bukan kewenangan dari Majelis Kehormatan Notaris Wilayah Provinsi DKI Jakarta diurutan ketiga ditahun 2019 yaitu Notaris Meninggal Dunia dengan jumlah 5 (lima) orang.

Jika yang dibutuhkan oleh Penyidik adalah Minuta Akta yang berada dalam penyimpanan Notaris, maka Majelis Kehormatan Notaris Wilayah Provinsi DKI Jakarta akan memberikan jawaban berupa persetujuan atau penolakan terhadap permohonan tersebut.

Majelis Kehormatan Wilayah Provinsi DKI Jakarta dalam mengetahui informasi mengenai Notaris yang masih hidup atau telah meninggal dunia berkoordinasi dengan Majelis Pengawas Daerah setempat. Jika Notaris tersebut telah meninggal dunia, maka Majelis Kehormatan Notaris Wilayah Provinsi DKI Jakarta menyatakan tidak berwenang untuk memberikan persetujuan dengan memberikan pernyataan bahwa Notaris telah meninggal dunia.

d. Tidak berkedudukan di DKI Jakarta;

Surat permohonan yang masuk ke Majelis Kehormatan Notaris Wilayah Provinsi DKI Jakarta yang bukan kewenangan dari Majelis Kehormatan Notaris Wilayah Provinsi DKI Jakarta diurutan keempat ditahun 2019 yaitu tidak berkedudukan di DKI Jakarta dengan jumlah 3 (tiga) orang

Tidak berkedudukan di DKI Jakarta dalam hal ini bisa terjadi apabila data Notaris tidak ditemukan di Majelis Pengawas Daerah setempat dikarenakan Notaris tersebut 
memang tidak ada (dengan indikasi Akta palsu) atau Notaris tersebut telah pindah tempat kedudukan

Jika yang dibutuhkan oleh Penyidik adalah Minuta Akta yang berada dalam penyimpanan Notaris yang berada di tempat kedudukan Notaris yang lama, maka Majelis Kehormatan Notaris Wilayah Provinsi DKI Jakarta menyatakan tidak berwenang untuk memberikan persetujuan terhadap Minuta Akta tersebut. Namun jika yang dibutuhkan adalah keterangan dari Notaris terhadap Akta yang dibuatnya walau berada di penyimpanan Notaris tempat kedudukan sebelumnya, maka Majelis Kehormatan Notaris Wilayah Provinsi DKI Jakarta seharusnya memberikan jawaban berupa memberikan persetujuan atau menolak terhadap pemanggilan Notaris tersebut ${ }^{13}$.

Dalam hal surat permohonan masuk adalah permohonan pemanggilan Notaris yang tidak berkedudukan di DKI Jakarta atau Minuta Akta Notaris tersebut berada dalam penyimpanan Notaris tempat kedudukan sebelumnya, maka Majelis Kehormatan Wilayah Provinsi DKI Jakarta menyatakan tidak berwenang untuk memberikan persetujuan tanpa perlu diadakan sidang terhadap Notaris terkait.

e. Notaris Pengganti;

Surat permohonan yang masuk ke Majelis Kehormatan Notaris Wilayah Provinsi DKI Jakarta yang bukan kewenangan dari Majelis Kehormatan Notaris Wilayah Provinsi DKI Jakarta dengan jumlah terendah ditahun 2019 yaitu Notaris Pengganti dengan jumlah 1 (satu) orang.

Sama halnya dengan PPAT, Majelis Kehormatan Notaris Wilayah Provinsi DKI Jakarta tidak berwenang untuk memberikan persetujuan baik terhadap Akta yang dibuat oleh Notaris Pengganti maupun pemanggilan Notaris Pengganti itu sendiri.

Majelis Kehormatan Notaris Wilayah Provinsi DKI Jakarta dalam menindaklanjuti surat permohonan yang masuk mengenai Notaris Pengganti, terlebih dahulu membentuk Majelis Pemeriksa untuk memeriksa Notaris yang pada saat itu digantikan Notaris Pengganti. Jika Notaris tersebut mengakui Akta tersebut memang bukan dibuat olehnya, maka Majelis Kehormatan Notaris Wilayah Provinsi DKI Jakarta menyatakan tidak berwenang untuk memberikan persetujuan atas Notaris Pengganti tanpa perlu memeriksa Notaris Pengganti tersebut.

Selain data yang didapat peneliti dari Majelis Kehormatan Notaris Wilayah Provinsi DKI Jakarta, peneliti juga mendapatkan data dari Majelis Kehormatan Notaris Wilayah Provinsi Banten sebagaimana penulis susun sesuai tabel dibawah ini:

13 Wawancara dengan Notaris Jakarta Selatan Taufik, S.H. selaku anggota Majelis Kehormatan Notaris Wilayah Provinsi DKI Jakarta pada tanggal 17 Januari 2019 pukul 14.00 di Kantor Notaris Taufik, S.H. 
Otentik's: Jurnal Hukum Kenotariatan (Vol 2, No. 1, Januari 2020)

p-ISSN 2655-5131 e-ISSN 2685-3612

Tabel 2. Surat Permohonan Masuk Per Bulan Januari Sampai Dengan September Tahun 2019 di Majelis Kehormatan Notaris Wilayah Banten

\begin{tabular}{|c|c|c|c|c|c|}
\hline \multirow{2}{*}{ BULAN } & \multicolumn{3}{|c|}{ JUMLAH SURAT MASUK } & \multirow{2}{*}{$\begin{array}{c}\text { BUKAN KEWENANGAN MAJELIS } \\
\text { KEHORMATAN WILAYAH } \\
\text { PROVINSI BANTEN }\end{array}$} \\
\cline { 2 - 5 } & $\begin{array}{c}\text { MENO } \\
\text { LAK }\end{array}$ & $\begin{array}{c}\text { MENERI } \\
\text { MA }\end{array}$ & $\begin{array}{c}\text { NOTARIS } \\
\text { PENGGA } \\
\text { NTI }\end{array}$ & PPAT & $\begin{array}{c}\text { TIDAK } \\
\text { BERKEDUDKAN DI } \\
\text { BANTEN }\end{array}$ \\
\hline Januari & 0 & 2 & & & 1 \\
\hline Februari & 1 & 8 & & & 1 \\
\hline Maret & \multicolumn{5}{|c|}{ MAJELIS PEMERIKSA BERHALANGAN HADIR, SEHINGGA } \\
DIJADWALKAN ULANG PADA BUKAN APRIL 2019
\end{tabular}

Sumber: Majelis Kehormatan Wilayah Banten

Dari data yang didapat peneliti dari Majelis Kehormatan Notaris Provinsi Banten menguraikan bahwa Majelis Kehormatan Notaris Wilayah Provinsi Banten yang terbentuk berdasarkan Keputusan Menteri Hukum dan Hak Asasi Manusia Republik Indonesia Nomor: AHU-16.HM.07.04 Tahun 2016 tentang Pengangkatan Anggota Majelis Kehormatan Notaris Wilayah Provinsi Banten tidak berwenang untuk memberikan persetujuan atas:

a. Pejabat Pembuat Akta Tanah (PPAT);

Surat permohonan yang masuk ke Majelis Kehormatan Notaris Wilayah Provinsi Banten yang bukan kewenangan dari Majelis Kehormatan Notaris Wilayah Provinsi Banten ditahun 2019 dengan jumlah 1 (satu) orang yaitu PPAT. Surat Permohonan terhadap pemanggilan PPAT disini adalah Notaris yang merangkap jabatan PPAT atau seseorang yang baru menjabat sebagai PPAT saja yang membuat Akta PPAT yang sebagaimana dijelaskan dalam ketentuan Pasal 2 ayat (2) Peraturan Kepala Badan Pertanahan Nasional Republik Indonesia Nomor 1 Tahun 2006 tentang Ketentuan Pelaksanaan Peraturan Pemerintah Republik Indonesia Nomor 37 Tahun 1998 tentang Peraturan Jabatan Pejabat Pembuat Akta Tanah yang terdiri dari: 
Otentik's: Jurnal Hukum Kenotariatan (Vol 2, No. 1, Januari 2020)

p-ISSN 2655-5131 e-ISSN 2685-3612

1) Akta Jual Beli;

2) Akta Tukar Menukar;

3) Akta Hibah;

4) Akta Pemasukan Ke Dalam Perusahaan (Inbreng);

5) Akta Pembagian Hak Bersama;

6) Akta Pemberian Hak Guna Bangunan/Hak Pakai Atas Tanah Hak Milik;

7) Akta Pemberian Hak Tanggungan;

8) Akta Pemberian Kuasa Membebankan Hak Tanggungan.

Akta Pemberian Kuasa Membebankan Hak Tanggungan sebagaimana dimaksud pada poin 8) adalah Akta yang dapat dibuat baik oleh Notaris ataupun PPAT, sehingga Akta Pemberian Kuasa Membebankan Hak Tanggungan yang dibuat oleh PPAT adalah bukan kewenangan dari Majelis Kehormatan Notaris Wilayah Banten. Sehingga dalam permohonan persetujuan terhadap pengambilan Minuta Akta maupun pengambilan PPAT, Majelis Kehormatan Notaris Wilayah Provinsi Banten menyatakan tidak berwenang untuk memberikan persetujuan atas hal tersebut.

Dalam hal surat permohonan masuk adalah pengambilan Minuta Akta maupun permohonan pemanggilan PPAT, maka Majelis Kehormatan Wilayah Provinsi Banten tetap melakukan pembentukan Majelis Pemeriksa dengan tidak menghadirkan Notaris dan/atau PPAT terkait.

b. Tidak berkedudukan di Banten;

Surat permohonan yang masuk ke Majelis Kehormatan Notaris Wilayah Provinsi Banten yang bukan kewenangan dari Majelis Kehormatan Notaris Wilayah Provinsi Banten ditahun 2019 dengan jumlah 1 (satu) orang yaitu tidak berkedudukan di Banten.

Tidak berkedudukan di Banten dalam hal ini bisa terjadi apabila data Notaris tidak ditemukan di Majelis Pengawas Daerah setempat dikarenakan Notaris tersebut memang tidak ada (dengan indikasi Akta palsu) atau Notaris tersebut telah pindah tempat kedudukan.

Jika yang dibutuhkan oleh Penyidik adalah Minuta Akta yang berada dalam penyimpanan Notaris yang berada di tempat kedudukan Notaris yang lama, maka Majelis Kehormatan Notaris Wilayah Provinsi Banten menyatakan tidak berwenang untuk memberikan persetujuan terhadap Minuta Akta tersebut. Namun jika yang dibutuhkan adalah keterangan dari Notaris terhadap Akta yang dibuatnya walau berada di penyimpanan Notaris tempat kedudukan sebelumnya, maka Majelis 
Otentik's: Jurnal Hukum Kenotariatan (Vol 2, No. 1, Januari 2020)

p-ISSN 2655-5131 e-ISSN 2685-3612

Kehormatan Notaris Wilayah Provinsi Banten akan memberikan jawaban berupa memberikan persetujuan atau menolak terhadap pemanggilan Notaris tersebut.

Dalam hal surat permohonan masuk adalah permohonan pemanggilan Notaris yang tidak berkedudukan di Banten atau Minuta Akta Notaris tersebut berada dalam penyimpanan Notaris tempat kedudukan sebelumnya, maka Majelis Kehormatan Wilayah Provinsi Banten menyatakan tidak berwenang untuk memberikan persetujuan tanpa perlu diadakan sidang terhadap Notaris terkait.

Berdasarkan data yang didapat oleh peneliti dari Majelis Kehormatan Notaris Wilayah Provinsi DKI Jakarta dan Majelis Kehormatan Notaris Wilayah Provinsi Banten terdapat perbedaan dalam mengambil keputusan terhadap permohonan pengambilan Minuta Akta dan pemanggilan Notaris Pengganti.

Majelis Kehormatan Notaris Wilayah Provinsi DKI Jakarta menganggap bahwa kewenangan yang dimiliki oleh Majelis Kehormatan Notaris pada umumnya hanya diatur dalam ketentuan Pasal 66 ayat (1) UUJN dan Pasal 20 Permenkumham MKN saja. Jika Majelis Kehormatan Notaris Wilayah Provisni DKI Jakarta beranggapan demikian, maka anggapan tersebut tidak salah, dikarenakan dalam ketentuan Pasal 66 ayat (1) UUJN dan Pasal 20 Permenkumham MKN "belum" mengatur mengenai ketentuan Notaris Pengganti.

Berbeda dengan Majelis Kehormatan Notaris Wilayah Provinsi DKI Jakarta, Majelis Kehormatan Notaris Wilayah Provinsi Banten menganggap bahwa Notaris Pengganti juga merupakan bagian dari kewenangan dari Majelis Kehormatan Notaris.

Dalam menafsirkan hukum terutama UUJN dan peraturan turunannya tidak bisa ditafsirkan berdasarkan aturan per pasal saja. Dalam menafsirkan UUJN dan peraturan turunannya harus ditafsirkan secara menyeluruh UUJN dengan tetap memperhatikan Hukum Umum terkait dan peraturan turunannya.

Notaris Pengganti sesuai ketentuan Pasal 1 angka 3 UUJN adalah seorang yang untuk sementara diangkat sebagai Notaris untuk menggantikan Notaris yang sedang cuti, sakit atau untuk sementara berhalangan menjalankan jabatannya sebagai Notaris.

Notaris Pengganti yang ditunjuk harus memenuhi syarat yang ditentukan dalam ketentuan Pasal 33 UUJN ayat (1) dan Pasal 27 ayat (3) Permenkumham Notaris yaitu:

a. Warga Negara Indonesia;

b. Berijazah Sarjana Hukum; dan

c. Telah bekerja sebagai karyawan Notaris paling singkat 24 (dua puluh empat) bulan berturut-turut. 
Otentik's: Jurnal Hukum Kenotariatan (Vol 2, No. 1, Januari 2020)

p-ISSN 2655-5131 e-ISSN 2685-3612

Notaris Pengganti biasanya merupakan karyawan Notaris terkait atau Alumni Mahasiswa Prodi Kenotariatan yang melakukan magang di kantor Notaris terkait. Hal ini dilakukan guna mempermudah Notaris dalam melakukan serah terima Protokol Notaris dan Notaris sudah mengetahui cara kerja Notaris Pengganti tersebut karena sudah bekerja sebagai karyawan Notaris selama 2 (dua) tahun lebih secara berturut-turut.

Berdasarkan ketentuan Pasal 29 Permenkumham Notaris, sebelum menjalankan jabatannya, Notaris Pengganti wajib mengucapkan sumpah/janji menurut agamanya di hadapan Menteri atau pejabat yang ditunjuk yang lafal sumpah/janji sesuai dengan sumpah/janji Notaris yang diatur dalam UUJN.

Berdasarkan ketentuan Pasal 1 ayat (3) dan Pasal 22 ayat (2) UUJN serta Pasal 27 ayat (3) Permenkumham Notaris tersebut adalah dimaksud untuk mengatur kedudukan hukum dari Notaris Pengganti yakni sebagai Notaris. Kedudukan demikian berarti Notaris Pengganti adalah pejabat umum sebagaimana dimaksud dalam ketentuan Pasal 1868 KUH Perdata.

Dalam ketentuan Pasal 65 UUJN pun menguraikan bahwa tanggungjawab Notaris Pengganti sama halnya dengan Notaris pada umumnya yaitu bertanggungjawab atas Protokol Notaris walau Protokol Notaris tersebut sudah diserahkan atau dipindahkan kepada pihak penyimpanan Protokol Notaris.

Atas alasan sebagaimana diuraikan diatas, peneliti setuju dengan keputusan dari Majelis Kehormatan Notaris Wilayah Provinsi Banten yang menganggap bahwa Notaris Pengganti merupakan bagian dari kewenangan Majelis Kehormatan Notaris mengingat prosedur menjalankan jabatan dan tanggungjawab dari Notaris Pengganti dan Notaris adalah sama.

Selain itu, jika diperkenankan, peneliti berpendapat bahwa tujuan awal dibentuknya Majelis Kehormatan Notaris bukan melindungi (jabatan) Notaris walau Notaris merupakan pekerjaan terhormat sekalipun. Tujuan awal dibentuknya Majelis Kehormatan Notaris adalah untuk melindungi produk Notaris yang berisikan mengenai kepentingan para pihak dan pihak ketiga. Sehingga apabila produk Notaris tersebut diketahui khalayak umum, maka akan berpotensi merugikan pihak terkait. Sehingga hemat peneliti, Notaris Pengganti, Pejabat Sementara Notaris dan Notaris Pensiun (Werda Notaris) seharusnya mendapatkan perlindungan yang sama dari Majelis Kehormatan Notaris.

Dalam UUJN dan peraturan turunannya belum mengatur mengenai ketentuan Notaris Pengganti. Hal inilah yang menyebabkan Majelis Kehormatan Notaris di wilayah yang berbeda akan menafsirkan UUJN dan peraturan turunannya secara berbeda pula. 
Otentik's: Jurnal Hukum Kenotariatan (Vol 2, No. 1, Januari 2020)

p-ISSN 2655-5131 e-ISSN 2685-3612

Sehingga untuk kedepannya agar pemerintah dapat merevisi UUJN dengan menambahkan ketentuan mengenai Notaris Pengganti, Pejabat Sementara Notaris dan Notaris Pensiun (Werda Notaris). Karena bukan tidak mungkin suatu saat Majelis Kehormatan Notaris tidak terkecuali Majelis Kehormatan Notaris Wilayah Provinsi Banten yang menganggap Notaris Pengganti merupakan kewenangan dari Majelis Kehormatan Notaris akan diajukan gugatan ke Pengadilan Tata Usaha Negara ${ }^{14}$, mengingat dalam UUJN dan peraturan turunannya belum mengatur secara eksplisit ketentuan mengenai Notaris Pengganti, Pejabat Sementara Notaris dan Notaris Pensiun (Werda Notaris).

Selain berpotensi akan diajukan uji materi lagi, dengan belum adanya ketentuan yang mengatur mengenai Notaris Pengganti, Pejabat Sementara Notaris dan Notaris Pensiun (Werda Notaris) akan menimbulkan celah hukum terhadap pengambilan Minuta Akta dan pemanggilan Notaris Pengganti, Pejabat Sementara Notaris dan Notaris Pensiun (Werda Notaris). Dalam proses peradilan, jika Penyidik, Penuntut Umum atau Hakim jika membutuhkan keterangan Notaris Pengganti, Pejabat Sementara Notaris dan Notaris Pensiun (Werda Notaris) baik sebagai Saksi, Ahli maupun Tersangka dapat memanggil Notaris tersebut tanpa persetujuan dari Majelis Kehormatan Notaris. Sehingga Rahasia Jabatan yang dimiliki oleh Notaris dan kewenangan Majelis Kehormatan Notaris saat ini akan kurang maksimal.

\section{KESIMPULAN}

1. Perlindungan Hukum terhadap Notaris diatur dalam ketentuan Pasal 66 ayat (1) UUJN dan Pasal 20 Permenkumham MKN yang berbunyi:

"Untuk kepentingan proses peradilan, Penyidik, Penuntut Umum atau Hakim dengan persetujuan Majelis Kehormatan Notaris berwenang:

a. Mengambil fotokopi Minuta Akta dan/atau surat-surat yang dilekatkan pada Minuta Akta atau Protokol Notaris dalam penyimpanan Notaris; dan

b. Memanggil Notaris untuk hadir dalam pemeriksaan yang berkaitan dengan Akta atau Protokol Notaris yang berada dalam penyimpanan Notaris.

Dalam ketentuan Pasal 66 ayat (1) UUJN dan Pasal 20 Permenkumham MKN belum mengatur mengenai Notaris Pengganti, sehingga jika Majelis Kehormatan Notaris Wilayah bermaksud memberikan perlindungan hukum terhadap Notaris Pengganti maka dapat mengkaitkan dengan ketentuan Pasal 65 UUJN yang menjelaskan

${ }^{14}$ Habib Adjie, Memahami: Majelis Pengawas Notaris (MPN) dan Majelis Kehormatan Notaris (MKN), Op.Cit., HIm 49. Sebagai bahan perbandingan Pengadilan Tata Usaha Negara Surabaya telah memerintahkan kepada ketua Majelis Pengawas Daerah Notaris Kota Madiun dengan Putusan Nomor: 25/G/2009/PTUN SBY, tanggal 27 Agustus 2009 untuk mencabut Keputusan Tata Usaha Negara Nomor: 8/MPDN/II/2009 tanggal 18 Februari 2009, Perihal Pemanggilan Notaris. Dalam putusan tersebut dapat disimpulkan bahwa Majelis Pengawas Daerah (yang kewenangannya sekarang ada pada Majelis Kehormatan Notaris) sebagai Badan atau Pejabat Tata Usaha Negara dan Putusannya dikualifikasikan sebagai Keputusan Tata Usaha Negara yang bisa menjadi objek sengketa di Pengadilan Tata Usaha Negara (PTUN). 
Otentik's: Jurnal Hukum Kenotariatan (Vol 2, No. 1, Januari 2020)

p-ISSN 2655-5131 e-ISSN 2685-3612

mengenai tanggung jawab Notaris Pengganti terhadap Akta yang dibuatnya sampai meninggal dunia.

2. Perlindungan Hukum terhadap Notaris yang diterapkan oleh Majelis Kehormatan Notaris Wilayah Provinsi DKI Jakarta adalah sebatas yang diatur dalam ketentuan Pasal 66 Ayat (1) UUJN dan Pasal 20 Permenkumham saja, sehingga Majelis Kehormatan Notaris Wilayah Provinsi DKI Jakarta tidak memberikan Perlindungan Hukum terhadap Notaris Pengganti. Berbeda dengan Majelis Kehormatan Notaris Wilayah Banten yang menerapkan Perlindungan Hukum terhadap Notaris dengan menafsirkan UUJN dan Permenkumham MKN secara utuh. Sehingga Majelis Kehormatan Notaris Wilayah Provinsi Banten memberikan Perlindungan Hukum terhadap Notaris Pengganti dengan mengkaitkan dengan ketentuan Pasal 65 UUJN menjelaskan mengenai tanggung jawab Notaris Pengganti terhadap Akta yang dibuatnya sampai meninggal dunia.

\section{DAFTAR PUSTAKA}

Buku

Darus, M. Lutfhfan Hadi, Hukum Notariat dan Tanggungjawab Jabatan Notaris, Yogyakarta: UII Press, 2017.

Soepratignya, Paulus J., Teknik Pembuatan Akta Kontrak, Yogyakarta: Cahaya Atma Pustaka, 2012.

Latumeten, Peter, Pertanggungjawaban Hukum Profesi Notaris Bersumber dari UndangUndang Jabatan Notaris dan Hukum Pidana”, Solo: Diskusi Hukum, 2015.

Raharjo, Satjipto, Ilmu Hukum, Bandung: PT Citra Aditya Bakti, 2000.

Tim Penyusun, Pedoman Penulisan Usulan Penelitian \& Tesis Tahun Akademik 2018/2019, Jakarta: Program Studi Kenotariatan Program Magister Universitas Pancasila, 2018/2019, Hlm 32.

Soerjono Soekanto, Sendi-Sendi Hukum dan Tata Hukum, Bandung: Citra Aditya Bakti, 1989, Hlm 17.

S, Laurensius Arliman, Notaris dan Penegakan Hukum Oleh Hakim, Cet.1, Yogyakarta: Grup Penerbitan CV BUDI UTAMA, 2015.

Adjie, Habib, Memahami: Majelis Pengawas Notaris (MPN) dan Majelis Kehormatan Notaris (MKN), Bandung, PT Refika Aditama, 2017.

\section{Jurnal}

Utami, Sri, "Perlindungan Hukum Terhadap Notaris Dalam Proses Peradilan Pidana Menurut Undang-Undang Nomor 2 Tahun 2014 Tentang Perubahan Atas UndangUndang Nomor 30 Tahun 2004 Tentang Jabatan Notaris", artikel pada Jurnal Repertorium, ISSN: 2355-2646, Edisi 3 Januari-Juni 2015.

Harahap, Zulkifli, Pemanggilan Seorang Notaris dan PPAT oleh Kepolisian Harus Seizin Majelis Pengawas Daerah, Edisi Mei Majalah Renvoi, Jakarta, Hlm. 6.

\section{Peraturan Perundang-undangan}

Kitab Undang-Undang Hukum Pidana [Wetboek van Strafrecht], Prof. Moeljatno, S.H., Cet. 29, Jakarta: PT Bumi Aksara, 2011. 
Otentik's: Jurnal Hukum Kenotariatan (Vol 2, No. 1, Januari 2020)

p-ISSN 2655-5131 e-ISSN 2685-3612

Kitab Undang-Undang Hukum Perdata [Burgelijk Wetboek], Diterjemahkan oleh R. Subekti dan R. Tjitrosudibio, Cet. 8, Jakarta: Pradnya Paramita, 1976.

Indonesia, Undang-Undang Republik Indonesia tentang Hukum Acara Pidana, Nomor 8 Tahun 1981.

Undang-Undang Republik Indonesia tentang Jabatan Notaris, Nomor 30 Tahun 2004.

Undang-Undang Republik Indonesia tentang Perubahan Atas UndangUndang Nomor 30 Tahun 2004 tentang Jabatan Notaris, Nomor 2 Tahun 2014.

Peraturan Menteri Hukum dan Hak Asasi Manusia Republik Indonesia tentang Susunan Organisasi, Tata Cara Pengangkatan Anggota, Pemberhentian Anggota dan Tata Kerja Majelis Pengawas, Nomor 40 Tahun 2015.

\section{Media Online}

Hukum Online, Miliki Hak Ingkar, Notaris Wajib Rahasiakan Isi Akta, (05 Juli 2012) terdapat disitus https://www.hukumonline.com/berita/baca/lt4ff5751b7abce/milikihak-ingkar--notaris-wajib-rahasiakan-isi-akta/.

Alwesius, Beberapa Catatan Berkaitan Dengan Beberapa Ketetuan Dalam UUJN dan Perubahannya (Revisi), (24 Januari 2014) terdapat di situs http://alwesius.blogspot.com/2014/01/beberapa-catatan-terhadap-uujn-yangbaru.html.

\section{Wawancara}

Wawancara dengan Notaris Jakarta Selatan Taufik, S.H. selaku anggota Majelis Kehormatan Notaris Wilayah Provinsi DKI Jakarta.

Wawancara dengan Eris Andriyansyah, S.H., M.H. selaku staf Sekretaris Majelis Kehormatan Notaris Wilayah Provinsi Banten. 